\title{
PENGGUNAAN PENDEKATAN INKUIRI MELALUI PENGAMATAN UNTUK MENINGKATAN MINAT DAN PRESTASI BELAJAR SISWA KONSEP REAKSI KIMIA KELAS VII H MTsN 7 KEDIRI
}

\author{
SITI MUTHORIKAH \\ MTsN 7 Kediri \\ e-mail: sitimuthorikah@mtsn7kediri.sch.id
}

\begin{abstract}
ABSTRAK
Kurikulum 2013 (K-13) membawa konsekuensi logis pada upaya peningkatan kualitas proses pembelajaran IPA yang disesuaikan dengan karakteristik dan lingkungan sekitar madrasah. Pembelajaran menekankan pada pemberian pengalaman secara langsung kepada siswa untuk memahami gejala yang terjadi sehingga dalam pelaksanaannya dibutuhkan strategi pembelajaran yang tepat. Oleh sebab itu, maka kami menyusun pembelajaran dengan pendekatan inkuiri melaui pengamatan untuk meningkatkan minat dan prestasi belajar siswa kelas VII H MTsN 7 Kediri. Penelitian yang kami lakukan adalah penelitian tindakan kelas yang terdiri dari dua siklus tindakan. Setelah dilakukan análisis dan refleksi pada siklus I, diperoleh data $72,5 \%$ siswa aktif dalam pembelajaran. Sedangkan pada siklus II meningkat menjadi $90 \%$. Sementara rata-rata hasil belajar siswa pada siklus I adalah 84 dan meningkat menjadi 91,5 pada siklus 2. Sehingga dari data tersebut dapat disimpulkan bahwa pendekatan inkuiri melalui pengamatan dapat meningkatkan minat dan belajar siswa pada konsep reaksi kimia
\end{abstract}

Kata Kunci: inkuiri, reaksi kimia, hasil belajar

\section{PENDAHULUAN}

Kurikulum 2013 (K-13) membawa konsekuensi logis pada upaya peningkatan kualitas proses pembelajaran IPA yang disesuaikan dengan karakteristik dan lingkungan sekitar madrasah. Proses belajar yang diharapkan melalui kurikulum ini bukan sekedar membahas materi dalam buku-buku panduan pelajaran atau menginformasikan pengetahuan kepada siswa, melainkan menekankan pada pemberian pengalaman secara langsung kepada siswa untuk memahami gejala yang terjadi sehingga dalam pelaksanaannya dibutuhkan strategi pembelajaran yang tepat.

Pembelajaran pada awal semester genap tahun 2019/2020 di kelas VII H MTsN 7 Kediri lebih banyak dilakukan di dalam kelas, kurang bervariasi, dan kurang memanfaatkan lingkungan sekitar sebagai sumber belajar. Materi pelajaran disampaikan secara teoritik dan tidak berhubungan dengan kehidupan nyata. Proses pembelajaran tersebut menimbulkan kecenderungan siswa bersikap pasif. Dinamika dan interaksi dalam kelas juga belum optimal. Akibatnya, penguasaan kompetensi masih rendah.

Oleh sebab itu perlu dilakukan Penelitian Tindakan Kelas (PTK) sebagai upaya memperbaiki proses pembelajaran agar menjadi lebih berkualitas sehingga penguasaan kompetensi siswa meningkat. Materi "Reaksi Kimia" membahas konsep tentang ciri-ciri reaksi kimia dan faktor-faktor yang mempengaruhi kecepatan reaksi kimia. Mencermati karakteristik materi ini, maka strategi pembelajaran lebih tepat menggunakan kegiatan eksperimen karena akan lebih faktual dan nyata sehingga siswa dapat menemukan sendiri konsep yang dimaksud. Proses pembelajaran tersebut sejalan dengan pembelajaran melalui pendekatan inkuiri.

Menurut Helen Ibe (2013), melalui penggunaan model pembelajaran inkuiri terbimbing, guru dapat memberikan kesempatan bagi siswa untuk belajar, berpikir kritis, dan berdiskusi di antara rekan-rekan mereka. Berdasarkan hasil penelitian Yono Edy Kristanto dan Herawati Susilo (2015) menunjukkan kemampuan berpikir kritis siswa yang dibelajarkan menggunakan model pembelajaran inkuiri terbimbing berbeda nyata dengan siswa yang dibelajarkan menggunakan model pembelajaran konvensional, dan hasil belajar sains kelas eksperimen berbeda nyata dengan kelas kontrol. 
Oleh sebab itu tujuan dalam penelitian ini adalah untuk mengetahui minat belajar dan hasil belajar siswa pada konsep reaksi kimia dengan pendekatan inkuiri malalui pengamatan di kelas VII H MTsN 7 Kediri semester genap 2019/2020.

Manfaat dari penelitian ini adalah memberikan pengalaman belajar yang nyata dan faktual bagi siswa. Mendorong pada guru agar tidak ragu mencoba variasi pembelajaran dan lebih kreatif merancang strategi pembelajaran. Memberikan sumbangan bagi sekolah dalam perbaikan proses pembelajaran untuk meningkatkan potensi belajar siswa yang akhirnya berpengaruh pada mutu sekolah.

\section{METODE PENELITIAN}

Subjek dalam penelitian adalah siswa kelas VII H pada semester genap tahun pelajaran 2019/2020 di MTsN 7 Kediri . Siswa kelas ini berjumlah 40 orang, dengan rincian 18 laki-laki dan 22 orang perempuan. Di bagi kedalam 9 kelompok, masing-masing kelompok terdiri dari 4-5 orang. Objek penelitian yaitu kualitas pembelajaran yang meliputi aktivitas siswa (motivasi belajar) dan hasil belajar/penguasaan kompetensi siswa.

Metode pengumpulan data yang dipakai dalam proses penelitian ini adalah: (1) Metode observasi partisipatif, yaitu mengamati secara intens tentang proses pembelajaran (motivasi siswa) di kelas dengan pendekatan inkuiri. Proses pengumpulan data dalam penelitian ini dilakukan secara terus-menerus selama penelitian berlangsung. (2) Metode tes tulis, yaitu menyampaikan sejumlah pertanyaan tentang materi pelajaran, setelah diterapkannya pendekatan inkuiri.

Teknik analisis data yang digunakan dalam penelitian ini adalah teknik analisis deskriptif kualitatif dan kuantitatif. Analisis deskriptif kualitatif digunakan untuk menganalisis data-data yang berupa proses kegiatan pembelajaran/motivasi belajar siswa (prosentase keaktifan siswa).

Tabel 1. Prosentase Keaktifan Siswa pada Tiap Siklus

\begin{tabular}{|l|c|c|c|}
\hline \multirow{2}{*}{ Kelompok } & \multicolumn{2}{|c|}{ Siklus 1 } & \multicolumn{2}{c|}{ Siklus 2 } \\
\cline { 2 - 4 } & Siswa aktif Siswa tidak aktif & Siswa aktif & Siswa tidak aktif \\
\hline & & & \\
\hline Jumlah & & & \\
\hline $\begin{array}{l}\text { Prosentase } \\
\text { keaktifan } \\
\text { siswa }\end{array}$ & & & \\
\hline
\end{tabular}

Sementara itu, teknik analisis deskriptif kuantitatif digunakan untuk menganalisis skor hasil belajar IPA siswa sesudah implementasi tindakan dilakukan.

Tabel 2. Hasil Tes Tertulis Siswa pada Tiap Siklus

\begin{tabular}{|l|l|l|}
\hline Keterangan & Siklus1 & Siklus 2 \\
\hline Nilai Tertinggi & & \\
\hline Nilai Terendah & & \\
\hline Rata-rata Nilai Siswa & & \\
\hline Ketuntasan Klasikal Belajar Siswa & & \\
\hline
\end{tabular}

\section{HASIL DAN PEMBAHASAN}

\section{Hasil}

\section{Aktifitas Siswa}

Pada setiap kegiatan pembelajaran diadakan observasi terhadap aktivitas siswa sebagai alat untuk mengetahui tingkat keterlibatan siswa dalam kegiatan pembelajaran. Keterlibatan 
siswa dalam kegiatan pembelajaran dapat mempengaruhi pemahaman siswa terhadap materi pelajaran. Pada saat pelaksanaan penelitian, guru (peneliti) melakukan observasi aktivitas siswa. Hasil observasi keaktifan siswa disajikan pada tabel 3 di bawah ini.

Tabel 3. Prosentase Keaktifan Siswa Kelas VII H pada Tiap Siklus

\begin{tabular}{|c|c|c|c|c|}
\hline \multirow{2}{*}{ Kelompok } & \multicolumn{2}{|c|}{ Siklus1 } & \multicolumn{2}{|c|}{ Siklus 2} \\
\hline & Siswa aktif & Siswa tidak aktif & Siswa aktif & Siswa tidak aktif \\
\hline $\mathrm{I}$ & 3 & 1 & 4 & 0 \\
\hline II & 2 & 2 & 3 & 1 \\
\hline III & 4 & 0 & 4 & 0 \\
\hline IV & 3 & 2 & 4 & 1 \\
\hline V & 3 & 1 & 3 & 1 \\
\hline VI & 4 & 1 & 5 & 0 \\
\hline VII & 4 & 1 & 4 & 1 \\
\hline VIII & 3 & 2 & 5 & 0 \\
\hline IX & 3 & 1 & 4 & 0 \\
\hline Jumlah & 29 & 11 & 36 & 4 \\
\hline $\begin{array}{c}\text { Prosentase keaktifan } \\
\text { siswa }\end{array}$ & $72,5 \%$ & $27,5 \%$ & $90 \%$ & $10 \%$ \\
\hline
\end{tabular}

\section{Hasil Belajar}

Pada setiap akhir siklus diadakan tes sebagai alat untuk mengukur pemahaman siswa terhadap materi pembelajaran. Pelaksanaan tes individual ini dilakukan setiap akhir pembelajaran. Tes tertulis yang digunakan berupa soal uraian. Ketuntasan belajar individual ditetapkan jika siswa mendapat nilai $\geq 76$ dan ketuntasan belajar klasikal ditetapkan $\geq 85 \%$ siswa mendapatkan nilai $\geq 76$. Data hasil tes setiap akhir siklus dan sebelum pelaksanaan tindakan disajikan dalam tabel 4 di bawah ini.

Tabel 4. Hasil Tes Tertulis Siswa Kelas VII H pada Tiap Siklus

\begin{tabular}{|l|c|c|}
\hline Keterangan & Siklus 1 & Siklus 2 \\
\hline Nilai Tertinggi & 100 & 100 \\
\hline Nilai Terendah & 50 & 70 \\
\hline Rata-rata Nilai Siswa & 84 & 91,25 \\
\hline Ketuntasan Klasikal Belajar Siswa & Tuntas & Tuntas \\
\hline
\end{tabular}

\section{Pembahasan}

\section{Aktifitas Siswa}

Kegiatan pembelajaran yang dilakukan pada siklus 1 yaitu mereaksikan air kapur dengan karbondioksida, nasi dengan Iodium, dan batu kapur dengan air. Siswa diminta mengamati secara berkelompok dengan panduan Lembar Kegiatan Siswa/LKS. Dari hasil observasi aktivitas siswa, pengamatan kelompok sudah berjalan efektif tetapi kurang maksimal. Mereka sibuk membaca petunjuk pada LKS. Hanya sebagian anggota kelompok yang saling mendiskusikan hasil pengamatan mereka. Di sini belum terlihat kerjasama yang baik antar anggota kelompok. 
Prosentase keaktifan siswa pada siklus $1(72,5 \%)$ belum memenuhi indikator kinerja. Analisis terhadap hasil tersebut dipaparkan berikut ini. Kegiatan pembelajaran yang dilakukan yaitu pengamatan air kapur, nasi, Iodium, vitamin $\mathrm{C}$, dan batu kapur yang diikuti diskusi kelompok sebenarnya sudah tepat, namun kendalanya siswa belum memahami yang harus dilakukan saat pengamatan.

Selain itu kerja sama antarsiswa juga perlu dilatih dengan bentuk kegiatan yang melibatkan siswa secara total, artinya masing-masing siswa dituntut untuk memberikan kontribusi secara aktif dalam kelompoknya. Hal tersebut tidak tercapai melalui kegiatan diskusi kelompok karena siswa cenderung sama dengan pendapat siswa lain dalam satu kelompok yang dianggap pintar.

Pada siklus 2, kegiatan pembelajaran diubah dengan melakukan pengamatan terhadap obyek yang sudah dilakukan tetapi dengan tujuan dan variasi yang berbeda. Yaitu mereaksikan antara air dan batu gamping dengan suhu air dan ukuran batu gamping yang berbeda. Setiap siswa dalam kelompoknya masing-masing terlibat secara aktif dalam melakukan percobaan dan mengamati hasilnya. Kerja sama dalam kelompok terlihat sangat baik. Pembagian tugas antar anggota kelompok sudah terlihat merata dan maksimal.

Pada saat mendiskusikan hasil percobaan, masing-masing siswa sudah berkontribusi secara aktif dalam kelompoknya. Hal ini disebabkan semua siswa ikut bekerja sama dalam melakukan percobaan dan mengamati hasilnya sehingga mereka mempunyai bekal pengetahuan yang hampir sama sebagai bahan diskusi kelompok. Siswa tidak lagi bergantung pada temannya yang dianggap pintar. Hal ini sejalan dengan hasil penelitian Hapsari, dkk. (2012) yang menemukan bahwa ada pengaruh secara signifikan penggunaan model pembelajaran inkuiriterbimbing dalam pembelajaran biologi terhadap kemampuan berpikir kritis siswa. Pembelajaran dengan model inkuiri terbimbing menjadikan siswa belajar sebagai pemikir, bukan hanya sebagai penerima pasif pengetahuan. Ciri utama dari pembelajaran inkuiri adalah menekankan aktivitas siswa secara maksimal yang diarahkan untuk mencari dan menemukan jawabansendiri dari sesuatu yang dipertanyakan (Sanjaya, 2011:196).

Prosentase keaktifan siswa mencapai $90 \%$ dan sudah memenuhi indikator kinerja yang ditetapkan. Hal ini sejalan dengan pendapat Helen Ibe (2013), bahwa melalui penggunaan model pembelajaran inkuiri terbimbing, guru dapat memberikan kesempatan bagi siswa untuk belajar, berpikir kritis, dan berdiskusi di antara rekan-rekan mereka Peningkatan keaktifan siswa yaitu dari 72,5\% menjadi $90 \%$ sejalan dengan perubahan bentuk kegiatan pembelajaran yang dilakukan. Peningkatan ini terlihat dari hal-hal berikut:

1. Aktif dalam pengamatan,

2. aktif dalam diskusi kelompok,

3. responsif terhadap penjelasan guru

\section{Hasil Belajar}

Hasil belajar individual maupun klasikal mengalami kenaikan yang signifikan. Meningkatnya nilai rata-rata siswa dan ketuntasan belajar secara klasikal tersebut menunjukan peningkatan pemahaman siswa terhadap materi yang dipelajari. Hal ini sejalan dengan hasil penelitian Yono Edy Kristanto dan Herawati Susilo (2015) bahwa hasil belajar kognitif dengan pembelajaran inkuiri terbimbing lebih tinggi dibandingkan hasil belajar kognitif pada pembelajaran konvensional.

Melalui pendekatan inkuiri dengan pengamatan, materi yang dibahas menjadi lebih nyata, lebih menarik, dekat dengan kehidupan sehari-hari siswa dan siswa mengalami sendiri sehingga pemahaman siswa lebih mendalam. Peningkatan aktivitas belajar siswa akan meningkatkan hasil belajar siswa (Hamalik, 2013:32). Menurut Hosnan (2014:344) pembelajaran inkuiri dianggap lebih bermakna, karena inkuiri menekankan pada pengembangan aspek kognitif, afektif, danpsikomotorik secara seimbang

Pada siklus 2 pengamatan dilakukan dengan mereaksikan antara air dan batu gamping dengan suhu air dan ukuran batu gamping yang berbeda. Kegiatan tersebut membuat siswa lebih termotivasi untuk mempelajari dan memahami materi pelajaran yang disampaikan. Siswa 
belajar dengan baik, karena mereka terlibat secara aktif dalam kegiatan pembelajaran dan berkesempatan untuk menemukan sendiri. Hasil belajar tersebut juga dipengaruhi oleh pengalaman siswa dengan dunia fisik dan lingkungannya melaui sumber belajar yang dirancang oleh guru. Hasil penelitian ini sesuai dengan penelitian yang dilakukan oleh Pekerti dkk. (2013) yang menemukan bahwa penerapan model pembelajaran inkuiri terbimbing berpengaruh signifikan terhadappeningkatan hasil belajar siswa.

Peningkatan pemahaman siswa juga sangat dipengaruhi keaktifan dan keterlibatan siswa dalam pembelajaran. Keaktifan dan keterlibatan siswa dalam proses pembelajaran merupakan salah satu faktor pendukung keberhasilan belajar. Hal ini dapat dilihat dari meningkatnya nilai rata-rata siswa yang sejalan dengan meningkatnya aktivitas siswa pada tiap siklus. Maikristina dkk. (2013) berkesimpulan bahwa pembelajaran inkuiri terbimbing dapat meningkatkanhasil belajar siswa dan keterampilan proses sains siswa pada materi hidrolisis garam. Peningkatan hasilbelajar ini karena penerapan model pembelajaran inkuiri terbimbing memberikan kesempatan bagi siswa untuk aktif dalam pembelajaran danmemperoleh pengalaman dan menemukan konsep bagi diri sendiri.

\section{KESIMPULAN}

1. Minat belajar siswa pada konsep reaksi kimia meningkat melalui pendekatan inkuiri dengan pengamatan di kelas VII H MTsN 7 Kediri.

2. Hasil belajar siswa pada konsep reaksi kimia meningkat melalui pendekatan inkuiri dengan pengamatan di kelas VII H MTsN 7 Kediri.

\section{DAFTAR PUSTAKA}

Hamalik, O. (2013). Proses Belajar Mengajar. Bumi Aksara: Bandung

Hapsari, D. P,. Sudarisman, S., Marjono. (2012). Pengaruh Model Inkuiri Terbimbing Dengan Diagram V (Vee) dalam Pembelajaran Biologi terhadap Kemampuan Berpikir Kritis dan Hasil Belajar Siswa. Jurnal, (Online) 4 (2014): 16-28, (http://download.portalgaruda.org/article. php?article=50691\&val=4057), diakses tanggal 15 September 2021.

Hosnan, M. (2014). Pendekatan Saintifik dan Kontekstualdalam Pembelajaran Abad 21. Bogor: Ghalia Indonesia.

Ibe, Helen, N.N. (2013). Effects of guided-inquir andexpository teaching methods on senior secondaryschool students' performances in Biology in Imo State. Journal of Education Research and Behavioral Sciences (Online) Vol. 2 (4), pp. 051-057, (http://www.apexjournal.org/JERBS), diakses tanggal 15 September 2021.

Kristanto, Y.E., Susilo, Herawati. (2015). Pengaruh Model Pembelajaran Inkuiri Terbimbing terhadap Kemampuan Berpikir Kritis dan Hasil Belajar IPA Siswa Kelas VII SMP. Jurnal. $\quad$ (Online),http://journal.um.ac.id/index.php/pendidikan-danpembelajaran/article/ view/7750/3569, diakses 15 September 2021.

Maikristina, N., I Wayan Dasna, I. W., Sulistina, O. (2013). Pengaruh Penggunaan Model Pembelajaran Inkuiri Terbimbing terhadap Hasil Belajar dan Keterampilan Proses Sains Siswa Kelas XI IPA SMAN 3 Malang Pada Materi Hidrolisis Garam. Junal (Online), http://jurnal-online.um.ac.id/data/artikel/168099EE989A697168C9762 6B63B8B4E4 .pdf) diakses 15 September 2021.

Pekerti, F. A., Jalmo, T., Marpaung, R. R. T. (2013). Pengaruh Model Pembelajaran Inkuiri Terbimbing terhadap Aktivitas dan Hasil Belajar Siswa. Jurnal, (Online), (http://jurnal.fkip.unila.ac.id/index.php/JBT/article/view/2191) diakses 15 September 2021

Sanjaya, W. (2011). Strategi Pembelajaran Berorientasi Standar Proses Pendidikan. Jakarta: Kencana 